\title{
SOCIAL DISTANCING UPAYA PENCEGAHAN PENYEBARAN COVID-19 PERSPEKTIF MAQASHID AL-SYARI'AH
}

\author{
Zezen Zainul Ali \\ Institut Agama Islam Negeri Metro, Lampung \\ Email: zezen.uje@gmail.com
}

\begin{abstract}
Pandemic COVID-19 has shocked the world the number of victims of this virus has also reached a high number, even in Indonesia the spread of this virus has spread over time, meeting the fallen victims saved, keep moving to prevent this virus, one can find by appealing to the public to do social ditance that is spending distance with others and avoiding the crowd, to asking the government to issue such as working from home, eliminating activities that involve many people to spend religious activities, this is a lot of pros and cons in the community, of course, the Muslim community, the reason is that social appeals are reinforced, there are no legal rules in Islam either in the Koran and Hadith. This study uses literature data that is analyzed qualitatively. and will discuss the law of the social using maslahah theory which maslahat is the goal of Islamic law (maqshid al-shariah).
\end{abstract}

Keywords: Social Distancing, Maslahah, Maqashid Al-Syariah.

\section{A. Pendahuluan}

Awal memasuki tahun 2020 dunia digemparkan dengan muncunya virus jenis baru yakni coronavirus (SARS-CoV-2) yang dapat menimbulkan penyakit yang bernama Coronoavirus Disese 2019 atau disingkat menjadi COVID-19, wabah virus COVID-19 secara tidak langsung menggerkan dunia global. Setelah diketahui asal mula virus ini berasal dari wilayah Wuhan, Provinsi Hubei,Tiongkok. Virus ini ditemukan pada akhir desember 2019 dan sampai saat ini sudah ratusan negara yang terkonfirmasi terjangkit oleh virus ini.

Seiring berjelanan waktu, virus ini mulai meneyebar ke berbagai negara, jumlah kasus terus bertambah bahkan angka kematian yang diakibatkan oleh virus ini semakin meningkat, WHO sebagai Organisasi Kesehatan Dunia menetap bahwa virus corona sebagai pandemi global. Kondisi seperti ini jelas merupakan kondisi yang tidak biasa karena sepanjang sejarah hanya ada beberapa kausus penyakit yang dapat digolongkan sebagai pandemi karena tingkat penyebaranya. ${ }^{1}$ yang mana gejala awal dari penyebaran virus ini adalah demam, keletihan, batuk tidak berdahak dan sesak nafas.

Pandemi merupakan sebuah epidemi yang telah mejangkiti banyak orang dan telah menyebar ke berbagai negara bahkan benua, epidemi dapat diartikan sebagai istilah yang digunakan dalam meghitung peningkatan jumlah kasus penyakit pada suatu tempat secara tiba-tiba. ${ }^{2}$ Pandemi covid-19 merupakan

1Eman Supriatna, “ Wabah Corona Virus Dsiase Covid 19 dalam Pandangan Islam” dalam Jurnal SALAM, Vol.7, No.6 2020, pp.555-564, h. 556.

2https://www.sehatq.com/artikel/covid-19-ditetapkan-sebagai-pandemi-apa-artinya diunduh pada 14 April 2020 
realitas global yang mempengaruhi tatananan kehidupan manusia, tanpa memandang negara, bangsa, agama, ras agama dan strata sosial. ${ }^{3}$

Di Indonesia, virus ini muncul pada akhir bulan Februari 2020, yang terdiri dari 2 pasian yang positif COVID-19, yang terkonfirmasi bahwa kedua pasien telah mengikuti suatu acara di Jakarta dan pasien berkontak langsung dengan Warga Negara Asing (WNA) asal Jepang yang tinggal di Malaysia. Seketika berita ini menjadi trending topik diberbagai media khususnya di Indonesia setelah Presiden Joko Widodo menggelar konfersi Pers terkait ditemukannya kasus COVID-19 pertama di Indonesia.

Sejak pertama kasus positif COVID-19 ini diumumkan pada tanggal 2 Maret 2020 lalu, virus ini menyebar dengan cepat keberbagai wilayah di Indonesia, dan provinsi DKI Jakarta menjadi wilayah terbanyak jumlah kasus pasien positif COVID-19 dengan jumlah 7.485 kasus. Sampai saat ini jumlah kasus positif di Indonesia mencapai angka 26.9940 kasus dengan 7.637 kasus sembuh dan 1.641 pasien meninggal dunia. ${ }^{4}$

Menyikapi hal ini pemerintah tidak tinggal diam, pemerintah terus berupaya untuk mencegah penyebaran COVID-19, beberapa kebijakan telah diambil oleh pemerintah indonesia yakni mensosialisasikan Social Ditancing atau yang sekarang istilahnya di ganti menjadi Physical Ditancing yang mana tujuannya sama-sama untuk mencegah penyebaran virus corona, hal ini berimas terhadap kebijakan pemerintah dalam menyikapi penyebaran COVID-19, seperti pembatasan kegiatan-kegiatan yang menimbulkan keramaian, yang dikhawatirkan akan memacu penyebaran COVID-19, imbasnya adalah Menteri Pendidikan dan Kebudayaan (Mendikbud) mengeluarkan Surat Edaran nomor 4 tahun 2020 pada tanggal 24 Maret 2020 tentang pelaksanaan Kebijakan Pendidikan dalam Masa Darurat Penyebaran COVID-19 yang didalamnya berisi pembatalan Ujian Nasional (UN) tahun $2020^{5}$ dan Proses Pembelajaran yang dilaksanakan di rumah, sejak saat itulah masyarakat Indonesia beramai-ramai maakai tagline dirumah aja.

Namun, pada pelaksaaannya social distancing menuai beberapa perdebatan, seperti halnya pemberhentian kegaiatn keagamaan yang mengumpukan masa yang besar seperti peniadaan kegiatan sholat berjamaah dan sholat jumat di masjid yang dikeluarkan oleh Majelis Ulama Indonesia (MUI) dan beberapa oramas islam besar yang ada di Indonesia. ${ }^{6}$ Lalu instruksi untuk tetap diam dirumah menuai kecaman dari berbagai lapisan masyarakat khususnya masyarakat dikalangan bawah yang menganggap ketika meraka tetap berada dirumah tanpa melakukan pekerjaan maka mereka tidak adakan mendapatkan penghasilan, jika tidak mendapatkan penghasilan makan tidak bisa memberi makan keluarga.

Memang kebijakan social distancing atau tetap dirumah saja jika dilihat dari dua sudut pandang, disisi pertama akan memberikan efek positi dan

${ }^{3}$ Faried F, dkk, Fikih Pandemi,(Jakarta: NUO Publising, 2020), h. 1.

4Tim Gugus Tugas Nasional Penanggulangan Covid-19 https:/ /covid19.go.id/p/berita/kasus-positif-covid-19-naik-467-orang-sebanyak-15-provinsi-taklaporkan-penambahan-kasus diunduh pada 02 Juni 2020.

5Zezen Zainul Ali, Darurat Sipil VS Karantina Wilayah, Mana yang Lebih Efektif?, dalam http:/ / kronika.id/darurat-sipil-vs-karantina-wilayah-mana-yang-lebih-efektif/ di unduh pada 14 april 2020

6Eman Supriatna, “ Wabah Corona .., h. 558. 
manfaat bagi pelakunya dan orang namun jika dilihat dari sudut pandang lain dapat juga menimbulkan efek negatif bagi pelakunya.

Lalu bagaimana islam menyikapi keaddan sosial seperti yang terjadi sekarang ini, dalam tulisan ini akan mengkaji tentang Social Ditancing dalam kajian fiqih khususnya yakni Maqosid Al-syariah agar terwujudnya kemaslahatan manusia, dan kajian mengenai Social Ditancing ini perlu dipaparkan sebagai pedoman bagi beberapa orang yang mash ragu dalam melaksanakannya karena secara tektualis belum ada dalam Al-Qur'an dan hadis yang membahas tentang ini. Kajian ini berdasarkan literatur dari kitab, buku, dan artikel-artikel jurnal yang dianalisa secara kualitatif.

\section{B. Pembahasan}

\section{B.1. Mengenal COVID-19 dan Social Distancing}

Coronoavirus Desease 2019 atau disingkat menjadi COVID-19 adalah nama penyakit yang disebabkan oleh vius jenis baru yakni coronavirus (SARS-CoV-2) atau sering disebut dengan virus corona. ${ }^{7}$ Virus ini dikonfirmasi berasal dari wilayah Wuhan, Provinsi Hubei,Tiongkok pada pada akhir desember 2019.

Coronavirus adalah virus RNA strain tunggal positif, tidak bersegmen dan berkapsul, virus ini tergolong ordo Nidovirales, satu keluarga dengan Coronaviridar, coronavirus sensitif terhadap panas dan dapat di nonaktfkan dengan cairan disinfektan yang mengandung clorin, eter, alkohol, detergen nonionik, kloroform dan pelarut lipid dengan suku 56 derajat dalam waktu 30 menit. 8

Jenis virus ini dapat dapat menginfeksi hewan, kasus pertama ditemukan di Amerika Serikat seekor harimau terinfeksi covid-19. ${ }^{9}$ Pada awalnya virus ini kenyakanya menginfeksi hewan dengan sirkulasi anata-hewan ke hewan, namun virus ini dapat disebut juga dengan virus zoonitik yakni virus yang dapat menyebar dari hewan ke manusia. Bayak hewan yang dapat membawa virus ini sperti kelelawar, tikus bambu dan musang yang mana hewan ini adalah host yang bisasa ditemukan. Pada faktanya kelelawar adalah sumber utama dalam penyebaran virus seperti SARS dan MERS. ${ }^{10}$

Sesorang yang terinveksi COVID-19 memiliki gejala yang bervariasi, gejala ringan, sedang dan berat. Untuk gejala berat yang dapat muncul adalah demam diatas 38 derajat, batuk, dan sesak nafas dan juga terkadang disertai dengan diare. Pada kasus brat virus ini dapat menyebabkan gagal ginjal, sindrom pernapasan akut, pneumonia bahkan kematian. ${ }^{11}$

Pada dasarnya virus corona tidak dapat hidup diudara atau tidak dapat hidup tanpa ada host atau inang atau melalui media seperti percikan ludah saat batuk atau bersin, cara penularan virus ini adalah melalui saluran pernafasan, virus ini juga dapat menular melalui kontak langsung dengan orang yang terinfeksi melalui cairan yang keluar saat batuk atau bersin, masa inkubasi virus

7Universitas Gajah Mada, Buku Saku Desa Tangguh Covid-19, 2020, h. 3.

8Yuliana, "Corona Virus Diseases ( Covid-19); Sebuah Kajian Literatur" dalam Wellness And Healty Magazine Vol 2, No.1, Februari 2020, 187-192, h. 188.

Innovative Survey Network \& AFC, Jawaban Seputar Virus Corona( Jakarta: ISN, 2020),h,13

10 Ibid, h. 189.

11Kementrian Kesehatan RI, Pedoman Kesiapsiagaan Menghadapi Infeksi Novel Coronavirus,( Jakarta: Dirjen Pencegahan dan Pengendalian Penyakit, 2020) ,h. 10. 
ini anatara 1-14 hari namun kebanyakan terjadi dihari ke tiga sampai hari ke tujuh. ${ }^{12}$

Virus SARS-COV2 menyebar melalui percikan air liur atau droplet. Ketika seseorang terinfeksi kemudian batuk atau bersin, droplet atau pericikan akan jatuh dipermukaan benda yang ada di dekatnya. ${ }^{13}$ Lalu saat ada orang lain yang belum terinfeksi secara tidak sengaja menyentuh permukaan benda terkena doplet, lalu menyentuk mulu, hidung, atau mata tanpa mecuci tangan dengan benar terlebih dahulu, ia akan beresiko tinggi tertular.

Jika kita cermati virus ini tidak tidak dapat hidup diudara atau berterbangan, namun penyebarannya harus melewati inang yakni melalui media seperti pericikan air ludah dari orang yang terkena infeksi, maka dalam hal ini diperlukan dalam mencegah penyebaran virus adanya pembatasan jarak atara sesama, hal ini sesuai dengan instruksi presiden yang menghimbau untuk melaksanakan social distancing.

Social distancing adalah suatu cara pencegahan dan pegendalian non-medis yang di terapkan untuk mencegah penyebaran COVID-19 dengan cara mengrangi kontak anatara mereka yang terinfeksi COVID-19, sehingga dapat menghentikan mata rantai penyebaran penyakit dalam suatu wilayah. ${ }^{14}$

Social distancing merupakan tindakan preventif dalam mencegah penyebaran virus dengan cara menjauhi keramaian, tidak bepergian kemanamana kecuali dalam keadaan darurat dan sebisa mungkin tidak keluar rumah, Social distancing dapat diartikan mejaga jarak sosial, sehingga akan menghambat penyebaran Coronavirus melalui atau percikan air liur kontaminasi droplet pada jarak yang dekat dengan orang yang terinfeksi. ${ }^{15}$ World Health Organisation (WHO) memberikan rekomendasi untuk menjaga jarak aman lebih dari 1 meter, dan beberapa pakar kesehatan juga menyarankan agar menjaga jarak aman setidaknya dua meter dari orang lain. ${ }^{16}$

Masyarakat diminta untuk menghindari kerumunan orang. Jika memang harus keluar, yang harus dilakukan adalah jaga jarak sekitar 1-2 dengan orang lain. Langkah mudah dalam melaksanakan Social Distancing adalah dengan tidak pergi ke pusat keramaian, yakni pasar, mal,bioskop, konser, sekolah. Sekaln dari itu, beberapa hal yang dapat dilakukan untuk mencegah penyebaran virus ini adalah :

1. Melakukan rapat secara online

2. Berkerja dari rumah atau Work From Home jika memungkinkan

3. Melaksanakan sekolah dari rumah atau online

4. Tidak keluar rumah jika tidak dalam keadaan darurat

5. Menggunakan masker ketika keluar rumah

6. Selalu menjada kebersihan

12Tim Kerja Kemendagri, Pedoman Umu Menghadapi Pandemi Covid-19,( Jakarta: Kemendagri: 2020), h. 11.

13Adityo Susilo, dkk," Cororavirus Disease 2019: Review of Current Literatures" dalam Jurnal Penyakit Dalam Indonesia, Vol.7, N0.1, Maret 2020, h. 46. April 2020.

14https://www.mohfw.gov.in/SocialDistancingAdvisorybyMOHFW.pdf Diunduh pada 15

15 Sumarto, Sekolah Covid-19, (Bengkulu: Literasiologi, 2020), h. 23.

16Vina Fadhrotul Mukaromah, "WHO Gunakan Istilah Physical Distancing, Ini Bedanya dengan Social Distancing" dalam https://www.kompas.com/tren/read/2020/04/01/061500965/who-gunakan-istilah-physicaldistancing-ini-bedanya-dengan-social?page $=2$ di unduh pada 15 April 2020 
7. Melakukan Pola Hidup Sehat (PHBS)

8. Selalu mencuci tangan.

9. Selalu menjaga jarak aman yakn 1-2 meter

Social distancing dapat diartikan juga sebagai upaya untuk senantiasa melakukan aktivitas dari rumah, tidak bertemu dan berkontak fisik dengan orang lain. seperti pertemuan keluarga, teman harus dibatasi. Jika tidak terlalu penting, agar lebih baik tetap melakukan aktivitas dirumah. ${ }^{17}$

Namun, Social distancing atau pembatasan sosial diartikan seperti orangorang harus membatasi kegiatan sosial dan berhenti berkomunikasi atar satu sama lain. Mengingat manusia adalah mahluk sosial, pembatasan sosial lebih salah diartikan menjadi pembatasan interaksi sosial padahal sebagai mahluk sosial manusia tidak dapat memenuhi kebutuhannya sendiri, oleh karena tetap harus ada batasan jarak antar manusia demi kehidupan sosial tetap dilakukan, maka hal ini istilah physical distancing lebih tepat digunakan, meskipun secara umum antara Social distancing dan physical distancing tidak berbeda.

Physical distancing merupakan istilah pengganti dari social distancing, yang pada intinya adalah sama-sama bertujuan mencegah penyebaran virus corona. ${ }^{18}$

\section{B.2. Maslahah dalam Penetuan Hukum}

Secara etimologis, arti al-maslahah dapat berarti kebaikan, kebermanfaatan, kepantasan, kelayakan, keselarasan, kepatutan. Kata al- maslahah dilawankan dengan kata al-mafsadah yang artinya kerusakan. ${ }^{19}$ Masalahah dalam bahasa indonesia dikenal sebagai maslahat, atau sesuatu yag dapat mendatangkan manfaat. ${ }^{20}$ sedangkan dalam KBBI maslahat diartikan sesuatu yang dapat mendatangkan faidah, kebaikan dan guna. ${ }^{21}$

Dengan demikian Maslahat dapat diartikan sebagai segala sesuatu yang mengandung manfaat dalam rangka untuk mempperoleh kebaikan dan menolak keburukan. Maslahah digunakan oleh para ulama ushul dalam menetapkan kepastian hukum yang secara eksplisit tidak diatur dalam Al-Qur'an maupun Hadis.

Dalam rangka mencapai kemaslahatan dan menetapkan suatu hukum islam, terdapat tiga macam maslahat yaitu maslahat mu'tabarah, maslahat mulghah dan maslahat mursalah.

Pertama, Maslahat mu'tabarah, meruapakn maslahat yang secara langsung diungkapkan dalam al-Qur'an maupun hadis Nabi. Kedua, maslahat mulghah, maslahah yang secara langsung bertentangan dengan ketentuan yang ada dalam

\footnotetext{
17Mukharom dan Havis Aravik, “ Kebijakan Nabi Muhammad SAW Mengenai Wabah Penyakit Menular dan Implementasinya dalam Konteks Menanggulangi Coronavirus Covid-19" dalam Jurnal SALAM, Vol.7, No.3, pp.239-246, h. 244.

18https:/ / tirto.id/arti-physical-distancing-dan-social-distancing-apa-perbedaannya-eHNf di unduh pada 15 April 2020.

${ }^{19}$ Asmawi, "KONSEPTUALISASI TEORI MASLAHAH" dalam Salam; Jurnal Filsafat dan Budaya Hukum, h. 314.

${ }^{20}$ Aminudin Slamet, “ Konsep Maslahah Mursalah Wahbah Zuhaili Relevansinya dengan Pernikahan Sirri di Indonesia" , UIN Maulana Malik Ibrahim, 2011, h. 42.

${ }^{21}$ Imron Rosyadi, "Pemikiran Asy-Syatibi tentang Maslahah Mursalah," Jurnal Profetika Studi Islam vol 14, no. 1 (Juni 2013), h. 82.
} 
dalam al-Qur'an maupun al-Hadits. Ketiga maslahat mursalah, maslahat yang tidak ada dan tidak bertentangan dalam al-Quran maupun hadis. ${ }^{22}$

Maslahah mursalah Menurut ahli ilmu ushul fiqih mempunyai arti suatu kemaslahatan, dimana syariat atau hukum Alloh tidak ditemukan dalam AlQur'an maupun hadis dan tidak ditemukan dalil atas pengakuan dan penolakan. ${ }^{23}$ Maslahat merupakan terminologi yang paling populer dalam pembahasan hukum islam. Hal ini disebabkan karena maslahat merupakan tujuan syara' dari ditetapkannya hukum Islam. ${ }^{24}$

Syariat atau aturan-aturan hukum sebagaimana diturunkan dalam rangka menjamin dan mencapai kemaslahatan bagi umat manusia. Tujuan yang terkandung dalam syariat ini lah yang dikenal dengan Maqashid Al-Syariah. ${ }^{25}$

Secara etimologi maqashid al-syari'ah mengandung arti maksud dan tujuan disyariatkannya hukum Islam. Kajian mengenai tujuan ditetapkannya suatu hukum Islam merupakan kajian dalam ushul fiqih dan kajian filsafat hukum Islam. ${ }^{26}$

Secara umum Maqashid al-syariah mempunyai dua pengertian, yakni pengertian yang bersifat umum dan khusus. Secara umum, Maqashid al-syariah mempunyai pengertian kandungan dari ayat atau hadis hukum dapat dipahami secara langsung, yang mana Alloh SWT dalam menurunkan ayat dan Rasulullah dalam menurunkan hadis adalah untuk kemaslahatan. ${ }^{27}$ Sedangkan pengertian Maqashid al-syariah yang bersifat khusus adalah dalam rangka mewujudkan kemaslahatan baik dalam al-Qur'an maupun Hadits. ${ }^{28}$

Tema penting dalam diskusi kemaslahatan tidak dapat dilepaskan dari Maqashid al-syariah bahkan menjadi begian sentral. Maqashid al-syariah sangat diperlukan dalam mengebangkan pemikiran untuk menjawab persoalanpersoalan baru seiring perkembangan zaman saat ini yang mana tidak tercover dalam Al-Qur'an dan Al-Sunnah.

Dalam menggali sebuah hukum mengenai persoalan-persoalan baru yang belum tercover tadi, Maqashid al-syariah diperlukan untuk memberi kepastiabn suatu peristiwa hukum dapat diterapkan atau tidak yang berdasarkan demi tercapainya kemaslahatan. ${ }^{29}$

Dalam mencapai kemaslahatan Maqashid al-syariah mempunyai 3 urutan skala prioritas yakni adl-dlaruriyyat, al-hajjiyyat, at-tahsiniyyat. 30

22Agus Hermanto, “Eksistensi Konsep Maslahat Terhadap Paradigma Fikih Feminis Muslim Tentang Hak dan Kewajiban Suami Isteri" dalam NIZHAM, Vol. 7, No. 02 Juli-Desember 2019, h. 264.

${ }^{23} \mathrm{Abd}$. Wahab Khallaf, Vm Ushul al-Fiqhi, (Jakarta : Majelis ATa li Indonesiyyin li alDakwah al-lslamiyah, 1973), h. 116.

${ }^{24}$ Agus Hermanto, “Eksistensi Konsep.., h. 436.

${ }^{25}$ Fatma Amalia, “Rancangan Undang-undang Kesetaraan dan Keadilan Gender(RUU KKG) dalam Tinjauan Maqasid Asy-Syariah”, dalam Musawa, Vol.11, No.2, Juli 2012, h. 214.

26Moh Khasan, "Kedudukan Maqashid Al-Syari'ah Dalam Pembaharuan Hukum Islam" dalam Jurnal Dimas Vol. 8 No. 2 Tahun 2008, h. 302.

27Ghofar Shidiq, "Teori Maqashid Al-Syariah dalam Hukum Islam" , Universitas Sultan Agung, Vol. XLIV, No. 118, Juni -Agustus 2009, h. 119.

${ }^{28}$ Ali Mutakin, "Hubungan Maqașid Al Syari' ah Dengan Metode Istinbath Hukum" dalam Jurnal Analisis, Volume 17, Nomor 1, Juni 2017, h. 115.

${ }^{29}$ Imam Mustofa, “Membangun Epistimologi Fikih.., h. 257.

30Yudian Wahyudi, Ushul Fikih Versus Hermeneutika Membaca Islam dari Kanada dan Amerika (Yogyakarta: pesantren Nawesea Press, 2006), h. 45. 
1. adl-dlaruriyyat (tujuan primer), yang mempunyai arti sebagai tujuan yang harus ada agar tegaknya kehidupan manusia, yang mana jika hal tersebut tidak ada atau tidak dapat tepenuhi maka akan berakibat fatal bahkan dapat menghancurkan kehidupan dan bersifat primer bagi kebutuhan manusia, seperti memelihara agama, akal, jiwa, keturunan dan harta atau kekayaan. 31

2. al-hajjiyyat (tujuan sekunder) yakni menghindarkan manusia dari hal-hal yang dapat menyulikan dan untuk memudahkan manusia dalam mencapai kepentingan-kepentingannya. Karena maslahat ini buian terasuk kedalam kebutuhan primer melainkan kebutuhan sekunder, maka ini dibutuhkan bukan diharuskan. dengan kata lain, jika hal-hal yang bersifat hajjiyyat tidak terpenuhi, maka tidak akan menimbulkan kerusakan terhadap kehidupan manusia hanya akan berdampak kepada kekurangan kenyamanan. 32

3. at-tahsiniyyat (tujuan tersier) yakni sesuatu yang keberadaanya tidak diharuskan maupun dibutuhkan, posisinya hanya sebagai pelengkap atau tersier. ketidak terpenuhinya at-tahsiniyyat ini tidak membuat kehancuran maupun mempersulit kehidupan hanya mengurangi keindahan. tujuan tertsier bersifat relatif dan terserah pada kemauan individu, selama tudak bertentangan dengan syariat. 33

Kajian teori Maqashid Al-syariah dalam rangka mencapai kemaslahatan adalah sangat penting. Urgensinya didasarkan pada pertimbanganpertimbangan sebagai berikut:

Pertama, hukum islam merupakan hukum yang berasal dari Allah SWT yang diperuntukan untuk kemaslahatan umat manusia. Yang mana akan selalu berhadapan dengan perubahan sosial yang ada pada masyarakat. Kedua, dari segi historis, perhatian terhadap teori ini telah dilakukan oleh Nabi Muhammad SAW, sahabat dan para mujtahid. Ketiga, sebuah keberhasilan bagi mujtahid dalam berijtihad dalam memahami maqashid al-syariah ${ }^{34}$

Maqashid al-syariah prinsipnya adalah hukum syariat dibuat dengan tujuan untuk mencapai kebahagiaan hidp, baik dunia maupun akhirat. ${ }^{35}$ Demikianlah, apabila kita cermati maqașid al-syariah, meruapakan maslahat dalam rangka mencapai tujuan utama Alloh SWT dalam membuat syariat-Nya yang diwujudkan demi kemaslahatan dan kesejahteraan manusia baik ukhrawi dan duniawi.

Menarik manfaat dan menolak kemadharatan merupakan inti dari maqashid al-syari'ah karena dalam penetapan hukum Islam harus berpatokan pada kemaslahatan. ${ }^{36}$

Maqashid al-syari'ah merupakan sebuah konsep penting dalam kajian hukum Islam. Karena urgesinya, maqashid al-syari'ah menjadi salah satu yang wajib dipahami oleh mujtahid dalam ijtihadnya.

\footnotetext{
31 Imam Mustofa, Kajian Fiqih Kontemporer, (Yogyakarta: Idea Press, 2017),h.201

${ }^{32}$ Yudian Wahyudi, Ushul Fikih.., h. 46.

33Ibid., h. 47.

${ }^{34}$ Ghofar Shidiq, “Teori Maqashid .., h. 119.

35Mukharom dan Havis Aravik, " Kebijakan Nabi Muhammad ..., h.245

36Hammam, "Urgensi Kaidah Fiqhiyyah Dalam Perumusan Hukum Dan Implemetasinya
} Dalam Fatwa DSN-MUI" dalam Et-Tijarie, Volume 4, Nomor 1, Januari 2017, h. 117. 


\section{B.3. Kajian Hukum Social Distancing}

Setiap tujuan hukum dalam Islam adalah kemaslahatan, baik di dunia maupun di akhirat. di kalangan para ulama, maslahat merupakan dalil dari salah satu dalil mukhtalif yang menjadi ikhtilaf dalam penggunaan metode mujtahid dalam berijtihad bahwa maslahat adalah semua tujuan syariat Islam (Maqashid alsyari'ah). ${ }^{37}$

Penulis menggunakan teori maslahah dalam rangka menganalisa persoalan baru yang muncul yang mana belum tercakup atau tercantum dalam Al-Qur'an maupun hadis seiring perubahan zaman. Dengan demikian kita dapat memahami dan menentukan hukum dari Social Distancing ini terlebih saat kondisi pandemi COVID-19 yang melanda Indonesia bahkan Dunia.

Pada dasarnya hukum dari Social Distancing adalah mubah atau boleh, sesuai dengan kaidah fiqih:

\section{"Hukum asal adalah boleh"}

Dapat kita pahami bahwa hukum asal dari segala sesuatu yakni mubah apabila tidak ada dalil yang melarangnya, seperti halnya Social Distancing. Namun hukum dari Social Distancing dapat bervarisasi sesuai dengan situasi dan kondisi , apakah wajib, mubah, makruh atau haram.

Social distancing dapat ditarik kesimpulan hukumnya dengan memakai landasan Maqashid Syariah, Social distancing menempati tingkatan daruriyah pada posisi hifz al-nafs, yakni dalam rangka menyelamatkan nyawa sendiri dan orang lain disekitar, ditengah pandemi COVID-19 ini penyebaran virus sangat cepat karena penularan melalui interaksi secara langsung dengan orang yang terinfeksi visus ini. Maka social distancing harus dilakukan dengan cara berdiam diri dirumah dan tetap menjaga jarak dengan orang disekitar dan orang yang menunjukan gejala-gejala dari COVID-19 ini, terlebih ketika berada di wilayah zona merah darurat corona, apabila social distancing ini tidak dilakukan, akan mengakibatkan penularan dari manusia satu ke manusia lainnya bahkan dapat menimbulkan kematian. maka tindakan social distancing ini harus dilakukan, dan secara otomatis hukumnya sudah tidak mubah akan tetapi meningkat menjadi wajib dalam rangka menjaga jiwa.

Dalam tingkatan hajiyyah, Social distancing tetap menempati posisi hifz alnafs ketika memang dibutuhkan dan sebaiknya dilakukan dengan tujuan untuk menghindari bahaya baik yang tidak mengancam jiwa sampai yang mengancam jiwa. Misalnya, di suatu daerah yang belum dinyatakan zona merah darurat COVID-19, atau masih dalam zona hijau sampai orange, maka Social distancing dalam hal ini sangat dianjurkan dalam rangka menghindari diri dari kemudrotan atau tertular virus ini, karena gejala dari virus ini muncul anata 1-14 hari, meskipun dia dinyatakan negatif, dalam menjaga kehati-hatian agar tetap dirumah, ketika dia memaksakan keluar pilihannya dalah dua, dia menularkan atau dia yang tertular. Beberapa kasus, pasien yang tidak ada gejala-gejala

${ }^{37}$ Agus Hermanto, “Konsep Maslahat dalam Menyikapi Masalah Kontemporer (Studi Komparatif al-Tufi dan al-Ghazali)" dalam AL-'ADALAH, Vol. 14, Nomor 2, 2017, h. 434.

38Duski Ibrahim, Al-Qawa'Id Al-Fiqhiyah (Kaidah-Kaidah Fiqih), (Palembang: AMANAH, 2019), h. 60 . 
terinfeksi COVID-19 pun dinyatakan positif. Maka kehatihatian dalam hal ini sangat diperlukan demi kemaslahatan.

Penulis berpendapat bahwa dalam rangka mencapai tujuan syariat dan menjaga keselamatan jiwa baik bagi diri sendiri maupun orang lain disekitar, social distancing hukumnya adalah mubah. Hal ini sebagaimana ditinjau dari kaidah-kaidah fiqih berikut:

1. Kaidah fiqih:

الضَّرَرُ يُزَالْ

"Kemudharatan harus dihilangkan."

2. Kaidah fiqih:

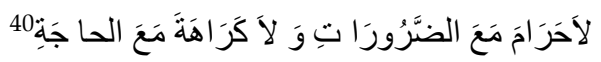

“Tiada keharaman bagi darurat dan tiada kemakmuran bagi kebutuhan"

3. Kaidah Fiqih:

إِذَاضَتَاقَ الأَمْرُ إنَّنَعَب1

"Kondisi yang mendesak dapat menimbulkan dispensasi"

4. Kaidah Fiqih:

ألضَّرَرُ يُدْفَعُ عَلَى قَدِرِ الإِنْكَانِ

"Kemudhratan harus dicegah sedapat mungkin."

Dari keempat kaidah diatas menjeaskan bahwa adalnaya ruqshah dalam keadaan darurat, suatu kemudaratan haruslah dihindari, sepertihalnya berkerumunan dengan orang banyak, ditengah kondisi darurat COVID-19 maka dalam rangka menghilangkan kemudorotatan makan berkerumun hukumnya dilarang. Karena tidk ada keharaman meninggalkan sesuatu apabila dalam keadaan yang darurat dan mendesak, seperti halnya dalam sholat berjamaah dimasjid dan sholat berjamaah dalam kondisi darurat dan mendesak akan adanya dispensasi atau ruqsah untuk meningglkannya dengan catatan tetap melaksanakannya dirumah, karena kemudorotah harus dicegah sedapat mungkin sehingga datanglah maslahat.

5. Kaidah Fiqih:

$$
\text { لاضررو لاضر ار }
$$

"Tidak boleh menyulitkan (orang lain) dan tidak dipersulit (oleh orang lain" 43

Dalam kaidah ini adalah kita sarankan agar tidak boleh menyulitkan orang lain dan kita juga tidak dipersulit orang lain, dalam kontek pandemi COVID-19 adalah kita tidak boleh menularkan virus ini ke orang lain atautun tertular dari

${ }^{39}$ Hammam, “Urgensi Kaidah .., h. 117.

40Duski Ibrahim, Al-Qawa'Id ..., h. 82.

${ }^{41}$ https:/ / sunni.co.id/ kaidah-fikih-idza-dhaqal-amru-ittasa-apabila-suatu-perkara-itusempit-maka-hukumnya-menjadi-luas/

42Ibid., h. 82.

43Ibid., h. 81. 
orang lain, maka hal yang harus dilakukan adalah melakukan social distancing dan selalu ada didalam rumah.

Dalam kondisi pandemi covid-19 kegiatan ibadah tidak boleh menimbulkan akibat bahaya baik kepada diri pribadi maupun orang lain, sholat jamaah di masjid berpotensi besar tersebarnya virus ini, karena potensi besar ini ulama menganjurkan untuk tetap beribadah sholat dirumah. ${ }^{44}$

6. Kaidah Fiqih :

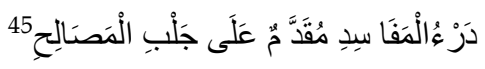

"Kemafsadatan di dahulukan dari pada mengambil kemaslahatan."

Dalam konteks kaidah ini adalah menolak kemudorotan lebih diutamakan dari mengambil keasalahatan atau manfaat, dalam pandemi dan situasi yang darurat, berdiam diri dirumah melakukan social distancing dan tidak melaksanakan sholat masjid dianggap boleh karena dalam rangka menjaga jiwa dan kemaslahatan, apabila keluar dikhawatirkan akan menulari atau tertular oleh orang lain, dalam posisi kaidah ini, menghindari kemafsadatan/kemudorotan adalah pencegahan agar tidak tertular COVID-19 dan mengambil kemaslahatan/manfaat adalah sholat di masjid.

Dalam tujuan syariah ( Maashid Al-Syariah) melakukan aktivitas dan ibadah tanpa dilandasi dalam rangka menjaga agama, keturunan, akal, harta, jiwa. Apapun ibadah yang dilaksanakan da berpotensi mengganggu kelima nilai tersebut maka wajib dihindari terlebih dahulu dari perkara ibadah biasanya. ${ }^{46}$

7. Kaidah Fiqih

"Segala perkara tergantung pada tujuannya."

الأمور بمقاصدها47 (n)

Berdasarkan kaidah ini, dapat kita pahami bahwa segala perkara terganntung pada niat dan tujuannya, maka hukum dalam melaksanakan social distancing bervariatif, pada dasarnya adalah mubah, namun hukumnya dapat bergeser pada makruh bahkan harap apabila dalam melaksanakannya minimbulkan mudorot dan membahayakan pada lima asas yakni agama, jiwa, akal, keturunan atau harta. Dalam keadaan normal pun social distancing dan berdiam diri didalam rumah adalah mubah, namun jika seorang laki-laki yang sudah mempunyai istri dan anak secara terus menerus di rumah dan tidak berkerja serta tidak menafkahi keluarganya dengan alasan yang tidak dibenarkan, maka hukumnya adalah haram. Sebagaimana tentang kewajiban mencari rezeki dalam Al-Qur'an surat al-jumuah ayat 110.

Soscial distancing dapat bergeser menjadi sunnah bahkan wajib apabila menibulkan memaslahatan baik bagi dirinya dan orang lain. Contohnya adalah ketika sesorang memiliki gejala-gejala COVID-19 bahkan positif, dan jika dia keluar rumah dapat menularkan kepada orang lain dan dapat membahayakan jiwa orang lain, makan diam dirumah dan mengkarantina diri hukumnya adalah

\footnotetext{
${ }^{44}$ Faried F, dkk, Fikih Pandemi..., h. 10.

${ }^{45}$ Ibid., h. 5.

46Ibid., h. 4.

47Duski Ibrahim, Al-Qawa'Id Al-Fighiyah..., h. 42.
} 
wajib. Bahkan dia diberikan keringanan( Ruqsah) untuk tidak melaksanakan shilat jumat dan tetap menggantinya dengan solat dzuhur.

Dari beberpa kaidah diatas, dalam keadaan darurat akan memunculkan dispensasi bagi manusia, dengan tujuan yaitu untuk mengambil suatu kemaslahatan baik bagi diri sendiri dan orang lain, karena menolak mudarat lebih diutamakan dari mengambil manfaat dalam rangka memelihara agama, jiwa, akal, keturunan dan harta.

Ada syarat-syarat umum dapat dilaksanakannya social distancing dalam rangka kemaslahatan, yakni:

1. Adanya peningakatn status darurat oleh otoritas pemegang kebijakan dalam hal ini adalah pemerintah terkait situasi dan kondisi yang sedang terjadi, dalam hal ini adalah penyebaran COVID-19.

2. Adanya pembagian wilayah atau zonasi tingkat keparahan yang diakibatkan suatu wabah, seperti zona merah adalah darurat, zona orange, waspada, zona hijau adalah siaga.

3. Bagi yang dinyatakan positif terinfeksi atau ada gejala maka wajib untuk mengkarantina diri dirumah.

4. Tindakan yang dilakukan (social distancing) harus mendatangkan mesalahatan, karena kemaslahatan adalah tujuan dari hukum islam, yakni dalam memelihara agama, jiwa, akal, keturunan dan harta sebagaimana tercantum dalam al-daruriyat maqashid al-syariah.

Dengan demikian, social distancing menjadi suatu pilihan dan cara dalam pencegahan penyebarah Covid-19. Dalam kontek keagamaan, tidak diperbolehkannya kegiatan keagamaan seperti sholat berjamaah, berkumpul untuk melksanakan pengajian, melainkan semata-mata untuk melindungi dirikita dan orang lain dari bahaya Covid-19.

\section{Simpulan}

Social Distancing sebagai tidakan dalam mencegah penyebaran COVID-19 memang pada dasarnya belum ada ketentuan yang mengatur baik dalam AlQur'an maupun hadis seiring perubahan zaman. Namun hukum islam akan selalu dapat menjawab persoalan-persoalnan baru yang muncul dalam rangka mencapai tujuan syariat (maqashid a-l-syariah) yaitu kemaslahatan. Seperti dalam dipembahasan diatas, hukum dari social distncing bervariatif tergantung pada situasi dan kondisi, akan tetapi pada dasarnya social distncing adalah mubah. Social distncing mempunyai kekuatan hukum wajib apabila dalam keadaan Daruriyah dan membahayakan jiwa, manakala dapat tapat tertular ataupun menulakan virus kepaada orang lain yang dapat mengakibatkan kematian. Social distncing hukumnya dapat berlaku haram ketika dalam keadaan normal, seseorang laki-laki yang sudah berkeluarga terus-terusan berada dirumah tidak berkerja dan menafkahi keluarganya dengan alasan yang tidak dibenarkan. Dalam tingkatan hajjiyah, social distancing dilakukan dalam rangka berhati-hati agar tidak tertular oleh virus ini dengan senantiasa selalu didalam rumah, dan ketika keluar rumah tetap menjaga jara dengan orang lain serta selalu menjaga kebersihan. 


\section{Referensi:}

Abd. Wahab Khallaf, Vm Ushul al-Fiqhi, Jakarta : Majelis ATa li Indonesiyyin li al-Dakwah al-lslamiyah, 1973.

Adityo Susilo, dkk," Cororavirus Disease 2019: Review of Current Literatures" dalam Jurnal Penyakit Dalam Indonesia, Vol.7, N0.1, Maret 2020.

Agus Hermanto, "Eksistensi Konsep Maslahat Terhadap Paradigma Fikih Feminis Muslim Tentang Hak Dan Kewajiban Suami Isteri" dalam NIZHAM, Vol. 7, No. 02 Juli-Desember 2019.

Agus Hermanto, "Konsep Maslahat dalam Menyikapi Masalah Kontemporer (Studi Komparatif al-Tufi dan al-Ghazali)" dalam AL-'ADALAH, Vol. 14, Nomor 2, 2017.

Ali Mutakin, "Hubungan Maqașid Al Syari'ah Dengan Metode Istinbath Hukum" dalam Jurnal Analisis, Volume 17, Nomor 1, Juni 2017.

Aminudin Slamet, " Konsep Maslahah Mursalah Wahbah Zuhaili Relevansinya dengan Pernikahan Sirri di Indonesia" , UIN Maulana Malik Ibrahim, 2011.

Asmawi, "Konseptualisasi Teori Maslahah" dalam Salam; Jurnal Filsafat dan Budaya Hukum.

Duski Ibrahim, Al-Qawa Id Al-Fiqhiyah (Kaidah-Kaidah Fiqih), Palembang: AMANAH, 2019.

Eman Supriatna, "Wabah Corona Virus Dsiase Covid 19 dalam Pandangan Islam" dalam Jurnal SALAM, Vol.7, No.6 2020, pp.555-564.

Faried F, dkk, Fikih Pandemi,Jakarta: NUO Publising, 2020.

Fatma Amalia, "Rancangan Undang-undang Kesetaraan dan Keadilan Gender(RUU KKG) dalam Tinjauan Maqasid Asy-Syariah", dalam Musawa, Vol.11, No.2, Juli 2012.

Ghofar Shidiq, "Teori Maqashid Al-Syariah dalam Hukum Islam" , Universitas Sultan Agung, Vol. XLIV, No. 118, Juni -Agustus 2009.

Hammam, "Urgensi Kaidah Fiqhiyyah Dalam Perumusan Hukum dan Implemetasinya Dalam Fatwa DSN-MUI" dalam Et-Tijarie, Volume 4, Nomor 1, Januari 2017.

https://sunni.co.id/kaidah-fikih-idza-dhaqal-amru-ittasa-apabila-suatuperkara-itu-sempit-maka-hukumnya-menjadi-luas /

https:/ / tirto.id/arti-physical-distancing-dan-social-distancing-apaperbedaannya-eHNf di unduh pada 15 April 2020

https://www.mohfw.gov.in/SocialDistancingAdvisorybyMOHFW.pdf Diunduh pada 15 April 2020

https://www.sehatq.com/artikel/covid-19-ditetapkan-sebagai-pandemi-apaartinya diunduh pada 14 April 2020

Imam Mustofa, Kajian Fiqih Kontemporer, Yogyakarta: Idea Press, 2017.

Imron Rosyadi, "Pemikiran Asy-Syatibi tentang Maslahah Mursalah," Jurnal Profetika Studi Islam, Vol 14, No. 1 Juni 2013.

Innovative Survey Network \& AFC, Jawaban Seputar Virus Corona, Jakarta: ISN, 2020.

Kementrian Kesehatan RI, Pedoman Kesiapsiagaan Menghadapi Infeksi Novel Coronavirus, Jakarta: Dirjen Pencegahan dan Pengendalian Penyakit, 2020.

Moh Khasan, "Kedudukan Maqashid Al-Syari'ah Dalam Pembaharuan Hukum Islam" dalam Jurnal Dimas Vol. 8 No. 2 Tahun 2008. 
Mukharom dan Havis Aravik, " Kebijakan Nabi Muhammad SAW Mengenai Wabah Penyakit Menular dan Implementasinya dalam Konteks Menanggulangi Coronavirus Covid-19" dalam Jurnal SALAM, Vol.7, No.3, pp.239-246.

Sumarto, Sekolah Covid-19, Bengkulu: Literasiologi, 2020.

Tim Gugus Tugas Nasional Penanggulangan Covid-19 https:/ covid19.go.id/p/berita/kasus-positif-covid-19-naik-467-orangsebanyak-15-provinsi-tak-laporkan-penambahan-kasus diunduh pada 02 Juni 2020.

Tim Kerja Kemendagri, Pedoman Umu Menghadapi Pandemi Covid-19, Jakarta: Kemendagri: 2020.

Universitas Gajah Mada, Buku Saku Desa Tangguh Covid-19, 2020.

Vina Fadhrotul Mukaromah, "WHO Gunakan Istilah Physical Distancing, Ini Bedanya dengan Social Distancing" dalam https://www.kompas.com/tren/read/2020/04/01/061500965/whogunakan-istilah-physical-distancing-ini-bedanya-dengan-social?page=2 di unduh pada 15 April 2020.

Yudian Wahyudi, Ushul Fikih Versus Hermeneutika Membaca Islam dari Kanada dan Amerika , Yogyakarta: pesantren Nawesea Press, 2006.

Yuliana, "Corona Virus Diseases ( Covid-19); Sebuah Kajian Literatur" dalam Wellness And Healty Magazine Vol 2, No.1, Februari 2020, 187-192.

Zezen Zainul Ali, Darurat Sipil VS Karantina Wilayah, Mana yang Lebih Efektif?, dalam http:/ / kronika.id/ darurat-sipil-vs-karantina-wilayah-mana-yanglebih-efektif/ di unduh pada 14 april 2020. 